\title{
DIE LIMINALE RUIMTE VIR INKONGRUENSIE TUSSEN PREDIKANT EN LIDMAAT: 'N NARRATIEF GEBASEERDE PRAKTIES-TEOLOGIESE ONDERSOEK IN GEMEENTES VAN die Nederduitsch Hervormde Kerk VAN Afrika
}

\author{
Authors: \\ Hein Delport ${ }^{1}$ \\ Julian C. Müller
}

\section{Affiliations: \\ ${ }^{1}$ Department of Practical Theology, University of \\ Pretoria, South Africa \\ Correspondence to: \\ Hein Delport}

email:

hmdelport@telkomsa.net

\section{Postal address:}

PO Box 115, Magaliesburg

1791, South Africa

\section{Keywords:}

liminal spaces,

incongruence; narrative

based research; practical theological examination; posfundationalism

Dates:

Received: 12 May 2010 Accepted: 11 Nov. 2010 Published: 02 Dec. 2010

How to cite this article: Delport, H., Müller, J.C., 2010, 'Die liminale ruimte vir inkongruensie tussen predikant en lidmaat: 'n Narratief gebaseerde prakties-teologiese ondersoek in gemeentes van die Nederduitsch Hervormde Kerk van Afrika', HTS Teologiese Studies/Theological Studies 66(2), Art. \#852, 6 pages. DOI: 10.4102/hts.v66i2.852

This article is available at:

http://www.hts.org.za

(C) 2010. The Authors. Licensee: OpenJournals Publishing. This work is licensed under the Creative Commons Attribution License.

\section{ABSTRACT}

Disagreements between pastors and church members in the Netherdutch Reformed Church of Africa (NRCH) require a unique space in the church in terms of a postmodern society. Different perspectives can easily lead to conflict in the Church. Unresolved conflict may jeopardise the work of the clergy in a congregation. In this research, I follow a contextual approach to the pursuit of practical theology. A postfundamental practical theological framework is followed in the research. The social construction discourse and narrative epistemology offer new perspectives for developing a liminal space where more than one perspective can exist. Within a society characterised by secularism and privatisation, I examine the possibility of a space of unity amid diversity in the Church. I involved six fellow researchers who have experienced conflict in a specific context within the Church. We also examined the possibility of an alternative space where moments of communitas can once again occur in these stories. The research found space for this in the description of two metaphors, namely the liminal suspension bridge of grace and the dance of peace. The stories of the fellow researchers are retold within these two metaphors. My research highlights the important contribution of an interdisciplinary conversation in research. In the study, the journey theme plays an important role, and the reader is invited along with the fellow researchers into a (liminal) space to explore the conflict between the church minister and the church member.

\section{INLEIDING}

\section{'n Kortsluiting}

'Ek is uitgekryt as 'n nar. ' $n$ Gek in die Kerk. 'n Hanswors.' 1

Min navorsing is al gedoen oor die liminale ruimte in die hoofstroomkerke in Suid-Afrika. Dit wil voorkom asof baie predikante vandag in die Afrikaanse kerke vasgevang word in 'n situasie van konflik in hul eie gemeentes. Daar ontstaan inkongruensie tussen die predikant en die lidmaat as gevolg van baie redes. Inkongruensie kan negatief wees, maar dit kan ook konstruktief aangewend word binne die Kerk. In hierdie teologiese navorsing gaan in besonder gevra word na 'n herformulering van 'n konflikverhaal om te sien of daar nie in die hervertelling van die verhaal 'n konstruktiewe ruimte bestaan vir die inkongruensie tussen predikant en lidmaat nie. Die vraag is: Hoe word iemand met 'n selfkonsep en selfbeskrywing van 'n gek of nar beweeg tot iemand wat weer hom- of haarself as geroepene van God beskou?

'n Kortsluiting kan op verskillende vlakke in die bediening voorkom, byvoorbeeld hermeneuties; in die kultuurkonteks deur sekularisme, individualisering, pluralisering, modernisering, mobilisering en selfs intensivering; op grond van die invloed van verskillende teologiese paradigmas; of dit kan selfs net 'n kortsluiting wees as gevolg van potensiële misverstaan tussen gelowiges in die Kerk. In die praxis kan 'n eenvormige herder-kudde-model selfs lei tot die uitbranding van 'n predikant in die Kerk, juis omdat van die predikant verwag word om verantwoordelikheid te neem vir die institusie, die individuele pastorale werk, die sosiale konteks en die geloofstradisie binne die Kerk, om maar enkele te noem. Dit alles gebeur oor 'n tydperk binne die ruimte van kerkwees, en wanneer daar verandering op die horison is, gebeur dit dikwels dat so 'n ruimte bedreig word en die worsteling verander in 'n kortsluiting vir die lidmaat of die predikant. So 'n verandering word gekenmerk deur meer as een perspektief op een saak binne die ruimte van kerkwees.

Volgens Pieterse (2005:78) is daar baie predikante in die Afrikaanssprekende kerke wat huiwer om met vrymoedigheid en oortuiging die boodskap van die Bybel as die Woord wat van God kom, aan die gemeente te bring. Pieterse beskryf in dieselfde artikel ook iets van die inkongruensie wat 'n gewone lidmaat en 'n predikant kan ervaar oor hierdie verskillende standpunte wat as gevolg van hul opleiding en agtergrond kan ontstaan.

Oliver (2006:1469) bestempel dit as 'n identiteitskrisis van Afrikaanse kerke in Suid-Afrika, wat sentreer rondom die Reformatoriese identiteit binne die kerk. Oliver sien die tradisionele metode van werk en skryf in Suid-Afrika in terme van ontwikkeling van 'n teologie verbind aan die Reformatoriese identiteit as 'n spesifieke ontwikkeling tot 'n persepsie van die Afrikanerspiritualiteit as gewortel in die Calvinistiese tradisie. Hierdie Calvinistiese perspektief gee aanleiding tot ' $n$ groter ervaring in die krisis vir die kerk. Die huidige situasie in die Afrikaanse kerke in Suid-Afrika vertel 'n meesterverhaal van sekularisme en pluraliteit van die postmoderne wêreld. Ek stem saam met Oliver (2006:1482) dat die invloed van postmoderniteit in Suid-Afrika en die kerk baie groter is as wat mense dink. Die kerk word gekonfronteer met die uitwerking van postmoderne denke op die samelewing, Afrikaners sien hulself

1. Geneem uit een van die vertellings van die medenavorsers in hierdie navorsing. 
as bystanders en doelbewus passief, of eerder as slagoffers van hierdie beweging binne die kerk.

\section{RUIMTE IS NODIG}

'Ek het besef dat dit vir' $n$ modernistiese persoon moeilik is, half onmoontlik om buite die kassie te dink....' ${ }^{2}$

In die antieke Grieks dui die term chora 'n ruimte of plek aan. Chorea is die werkwoord afgelei van die stamvorm chronos of chora wat 'n oop land of ruimte aandui. Dit kan selfs beteken om ruimte te gee. Enige mens het hierdie veilige tuiste of plek nodig. Tog, soos in enige ruimte, ook in die ruimte van gemeentes en kerkwees, is daar kantlyne waarbinne 'n mens moet beweeg. Mense is gedurig besig om alles op te deel in besitlikheid. Omdat mense voel dat hulle 'n plek nodig het, is hulle geneig om hierdie grense van hul eie te beskerm; 'n mens beskerm dit wat jou eie is. Ander mense kan ingelaat word, maar slegs op sekere voorwaardes. Binne hierdie grense is mense vry om te wees wie en wat hulle is. Jy kan veilig voel, en dit is belangrik vir die mens. Volgens Bons-Storm kan meeste van die konflik wat tussen mense bestaan, beskou word as gevegte oor die grense van hul eie belange of plekke.

Van Huyssteen se groot diagnose as verskil tussen modernisme en postmodernisme lê in die gedagte van fundamentalisme. Volgens Wildman meen Van Huyssteen dat modernisme bevestigend staan teenoor fundamentalisme, terwyl postmodernisme die rasionaliteit of perspektief ontken (Le Ron Shults 2006:38). Volgens Müller (2008:2) kan 'n fundamentalistiese perspektief beskou word as 'n denksisteem waar ' $n$ absolute waarheid beskikbaar is vir enigiemand wat daarna vra. 'n Teorie wat gebou word op so 'n perspektief kan beskou word as 'n universele rasionaliteit. Hier geld die voorveronderstelling dat daar 'n algehele raamwerk van verwysing bestaan wat in geheel as die waarheid beskou kan word. Daar is dus net een teoretiese waarheid, en hierdie waarheid moet nagevors en gevind word. Op sy beste kan die proses beskou word as 'n assimilasieproses waar ander standpunte slegs geakkumuleer word op die eie standpunt en vertrekpunt van die navorser. Om hierdie perspektief te verduidelik, gebruik Müller (2008:3) die voorbeeld van die bekende gesprek wat gevoer word deur teoloë en natuurwetenskaplikes. 'n Bekende voorbeeld hiervan is die konflik wat ontstaan tussen die kreasionis en die evolusionis. Müller (2008:3) kom tot die slotsom dat die enigste wyse waarop 'n fundamentalistiese perspektief 'n universele rasionaliteit kan poog, is deur middel van akkumulasie en inkorporasie.

Vir Van Huyssteen (1997:574) kan die vraag na verskillende perspektiewe wat gebore word uit'n beskouing van die wêreld, op 'n paar maniere gevra word om die invloed daarvan op teologie te bespeur. ' $n$ Fundamentele vraag volgens hom is of postmoderne godsdienstige gesprekvoering enigsins ' $n$ moontlikheid is vandag. Postmoderne denke daag die teoloë uit om te praat oor die 'feitlikheid' van die Christendom en om weer die verduidelikingsfunksie van godsdienstige ervarings in ' $n$ teologie te beskryf wat verby die fundamentalistiese denksisteem beweeg in die opsig dat die postmoderne beskouing ' $n$ werklikheid is. Een van die grootste uitdagings vir Van Huyssteen (1997:574) bly daarom die vraag: Kan navorsers voldoende aandag gee aan die probleem van die vorming van rasionaliteit en daardeur selfs die identiteit van 'n epistemologiese waarde, wat godsdiens vorm, in 'n postmoderne konteks? Vir ' $n$ interdissiplinêre gesprek is hierdie vraag van groot belang.

Newlands sien ' $n$ ander gevaar vir die praktiese teologie in fundamentalistiese denke. Volgens Newlands kan gevaar gesien word in terme van ' $n$ diskriminasie. Indien dit waar is dat absolute mag (of magteloosheid) die geneigdheid het om absolute inkongruensie te veroorsaak, wil dit vir hom voorkom asof fundamentalisme (nie altyd nie) kan lei tot diskriminasie. Geloof verander so in fantisisme. So kan 'n ongevormde ortodoksie verander in 'n eksklusiewe fundamentalistiese beskouing, 'n liberale teologie kan skuif na 'n reduksionistiese fundamentalisme. Dieselfde manier van dink kan ook toegepas word op die belydenisskrifte van enige kerk (LeRon Shults 2006:396-397).

Dié Antifundamentalistiese of diverse perspektief kan gesien word as 'n teenreaksie op die vorige, fundamentalistiese, perspektief. Volgens Müller (2008:3) neem hierdie perspektief die standpunt in dat geen fondament in die waarheid kan bestaan nie. In die denksisteem het die navorser net met ' $n$ diversiteit van denke te make. In hierdie denksisteem is interdissiplinêre gesprekvoering nog meer ingewikkeld, indien dit wel bereik kan word. Daar heers 'n algemene skeptisisme in die denksisteem oor onderlinge verstaan van die waarheid. Konstruktiewe gesprekvoering is amper onmoontlik in 'n situasie waar alles as relatief en subjektief beskou kan word.

'n Postfundamentalistiese of transversale perspektief staan krities teenoor albei bogenoemde denksisteme of posisies wat die navorser kan inneem. Die postfundamentalistiese perspektief is sensitief vir die gevaar van relativering sowel as subjektivering in rasionaliteit wat beskou kan word as 'n multivers. Hiermee streef 'n postfundamentalistiese perspektief verby die rasionaliteit van postfundamentalisme sowel as antifundamentalisme. Van Huyssteen (2000:427) herdefinieer die debat tussen teologie en wetenskap deur dit te sien as 'n groter en meer komplekse intellektuele uitdaging. Vir hom kan die aard en status van 'n interdissiplinêre refleksie moontlik aanleiding gee tot die manier waarop teologie en Godsdenke in die multidissiplinêre wêreld van navorsing hoort. Hier kan die dialoog tussen dissiplines en teologie gesien word as twee paaie wat besig is om met tyd tot een weg te ontwikkel. Verskillende stemme is dus nie noodwendig in kontradiksie nie en word nie noodwendig deur mekaar bedreig nie, maar kan eerder gesien word as in dinamiese interaksie met mekaar. In 'n multidissiplinêre gebruik van rasionele denke, wat Van Huyssteen beskryf as transversaal, is daar 'n familieverband tussen die verskillende stemme van dissiplines sigbaar. Hy vergelyk hierdie verskynsel met verweefde veseldrade, 'n dinamiese bewussyn, wat gesien kan word as 'n oorkruising of selfs oorvleuelend, sonder dat hierdie drade identies word in die verweefdheid. Die rasionaal van Van Huyssteen (2000:429) voorsien dus 'n filosofiese venster waardeur teologie na die wyer wêreld van denke en aksie kan kommunikeer. Dit kan verder gesien word as 'n sterk teenreaksie op die rasionaliste oftewel die modernis wat daarna streef om alle kennis te verbind tot 'n universele waarheidsbegrip. Hierdeur reageer Van Huyssteen (2000:429) ook teen die positivistiese begrip dat wetenskap as 'n superieure vorm van kennis gesien kan word. Dit kan ook gesien word as ' $n$ protes teen imperialisme en alle vorme van ideologiese denke. In hierdie rasionaliteit val die klem op 'n dialoog tussen verskillende gespreksgenote, en so word daar ook 'n vorm van belang vir die ander gespreksgenoot gekweek.

Die gedagte van 'n transversale rasionaliteit kan gesien word as die ruimte wat geskep word deur navorsers in hierdie denksisteem om 'n werkbare metode daar te stel waarbinne 'n interdissiplinêre gesprek moontlik is.

Volgens Müller (2008:4) noodsaak hierdie denksisteem die navorser om ten eerste na die verhale van mense in werklike lewensituasies te luister. Die doel is nie om hierdie situasies bloot te beskryf nie, om die konteks net te beskryf nie; eerder word die navorser gekonfronteer met 'n spesifieke en konkrete situasie. Die benadering kan gesien word as 'n posisie waarbinne die navorser die hermeneutiese aard van die situasie beleef.

\section{LIMINALE RUIMTE}

Die term liminale ruimte vind sy oorsprong in etnografie; die woord het egter verskeie vorme van betekenis in verskillende vakgebiede aangeneem. Arnold van Gennep et al. (2004) beskryf 
die ontwikkeling van 'n groep in drie terme: pre-liminale, liminale en postliminale bewegings. In 'n pre-liminale fase vind daar 'n skeiding plaas tussen die individu en die wêreld waartoe hy of sy behoort. Na hierdie skeiding is die persoon in Van Gennep (2004 et al.) se liminale fase, wat gesien en gedefinieer kan word as ' $\mathrm{n}$ sosiale en religieuse niemandsland. In hierdie sogenaamde leegte is ' $n$ persoon tussen twee vorme van selfkonseptualisering. ' $n$ Persoon word hier voorgestel aan 'n konsep van ' $n$ nuwe rol in die gemeenskap of groep. Die fase word gekenmerk deur bedreiging van ander of die individu en kan beskou word as 'n oorgangsfase. Die finale beweging kan gesien word as 'n postliminale beweging. Daar is oor die grense beweeg en die indvidu aanvaar sy of haar rol as deel van die verantwoordelikheid binne die groep of gemeenskap; dit kan beskou word as ' $n$ proses van herinlywing. Turner het verder onderskei tussen drie komponente in die liminale ruimte: die kommunikasie van die sacra, dekonstruksie en herkombinasie, die vereenvoudiging van die verhoudings in die sosiale struktuur. Dit is in hierdie derde komponent in die liminale ruimte dat die afstand tussen mense kleiner word en oomblikke ontstaan van absolute gelykheid. Turner het dit beskou as communitas. In sy navorsing het hy waargeneem dat persone binne die liminale fase gelykwaardig behandel word, gestroop van alle kenmerkende karaktertrekke van sosiale struktuur. Hier kom 'n 'nuwe' gemeenskap tot stand. 'n Gemeenskap waar die persone mekaar beskou as kamerade waar daar nie' $n$ hiërargiese struktuur in die gemeenskap bestaan nie, maar eerder klem gelê word op die relasionele verhoudings. So kan communitas gesien word as opponerend teenoor die struktuur, met ander woorde verskyn dit waar die struktuur nie die middelpunt inneem nie. Die dialektiese verhouding tussen struktuur en communitas is duidelik sigbaar. Wanneer communitas gemaksimeer word, word die maksimasie van die struktuur uitgedaag, wat weer aanleiding gee tot revolusionêre optrede vir 'n vernuwende communitas.

\section{Die dans van vrede}

Met die dans-van-vrede-metafoor vind ons aansluiting by baie ander teoloë wat diverse perspektiewe op so 'n manier aanbied (Buitendag 2002:948; Müller 2000:72; Gergen n.d. Dialogue, Life and Death of the Organization; Schutte \& Dreyer 2006:973; Bons-Storm 2008:150; Cilliërs 2007:14-17). Volgens Buitendag (2002:948) behoort 'n mens nie van buite oor postmoderniteit en die samelewing te praat nie. Deur die postmoderne mens te vergelyk met ' $n$ danser in die samelewing waar werklikhede gekonstrueer word, kan eerder oor postmoderniteit gepraat word in terme van ' $n$ dinamiese vorentoe en agtertoe, van binne uit, en kan ons ons subjektiewe waarneming en ervaring onder woorde kry. Daar kan gevra word: Na watter danse word ek genooi wanneer sekere uitdrukkings in taal gebruik word teenoor ander uitdrukkings van verstaan wat taal kan bied?

Vir Müller (2000:72) moet 'n model in die paradigma van die narratief nie bewegings beskou as stappe of fases nie. Dit kan eerder as ' $n$ dans-model gesien word as wat daarna verwys word as 'n strategiese model. Die klem val eerder op die sirkelvormigheid as op 'n liniêre beweging. Die terapeut/ navorser/gespreksgenoot se taak is om vyf groot verhale te vertel: die noodverhaal; die verhaal van die verlede; die toekomsverhaal; die hervertelde verhaal van die verlede; die verbeelde toekomsverhaal.

Inter-patie skep 'n atmosfeer vir die danssaal. Inter-patie kan gesien word as 'n doelbewuste kognitiewe voorstelling en affektiewe ervaring van iemand anders se denke en gevoel selfs al word die denke gevorm uit'n ander proses van rasionaal, en die gevoelens gekonstrueer uit 'n ander aannamebasis. Dit kan gesien word as meer as bloot simpatie. Dit is ' $n$ inklusiewe beweging wat gerig is tot die individu, maar ook tot kulture en waardes. Binne hierdie poreuse hermeneutiek word die voorgestelde grense van die epistemologie weer besoek, gereeld besoek: heen en weer, in die gees van om by iemand anders te leer. Hier word die geloof van mense die agent waar hulle beweeg van 'n status quo na 'n status flux. 'n Goeie beskrywing hiervan is dié van ' $n$ dans tussen jou en iemand met ' $n$ ander perspektief. Die eerste stap is, soos Bons-Storm (2008:150) dit beskryf, ' $n$ bewuswording van jou dansmaat. Die sien van jou dansmaat - nie om heeltyd na jou eie bewegings te kyk nie, maar om deel te word van die vloei van die hele proses of die dans. Die tweede stap van hierdie dans is om die mense rondom jou se andersheid te erken. 'n Derde gedeelte kan bygevoeg word, naamlik die erkenning van iemand anders se ruimte binne jou ruimte. So kan op 'n narratiewe manier 'n ruimte gekonstrueer word waarin verskillende perspektiewe aanwesig kan wees.

Buitendag (2002:941) sien die samelewing as 'n gemoedelike dans - elke mens op sy of haar eie, maar tog ritmies en skeppend in harmonie met die res. In so 'n postmodernistiese perspektief van die werklikheid gaan dit sowel om die enkeling as die groep. Hy beskryf hierdie dans as die kwantum-dans, omdat dit voortdurend spontaan en totaal onvoorspelbaar ontwikkel en omdat die verhoudings onderling die wesenlike van alles uitmaak. Hier weet die kwantumdansers sonder om te praat of oogkontak te maak wat die volgende beweging sal wees, omdat elkeen so geïntegreer is met die geheel. So kan daar volgens hom byvoorbeeld presies dieselfde beweging of ook presies die teenoorgestelde beweging gelyktydig deur verskillende dansers intuitief uitgevoer word - telkens sonder dat ooreengekom is. Indrukwekkend van hierdie perspektief van die werklikheid in die postmodernistiese paradigma is die gedagte dat nuwe werklikhede spontaan deur hierdie dans of aksie geskep word. Hy sien die mens as ' $n$ mens deur ander mense, binne ' $n$ bepaalde nis.

\section{Hoe lyk die danssaal?}

Die dans-van-vrede kan nie net gesien word as ' $n$ metode om na die inkongruensie van predikant en lidmaat te kyk nie; dit is verder ook ' $n$ ruimte wat deur die dansmaats voorgestel word. Wanneer ons na 'n dans uitgenooi word, kan ons onsself vir ' $n$ oomblik losmaak van een wêreld en genooi word in ' $n$ ander wêreld in. Hier stel die dansmaats geen reëls nie. Hier is ook geen struktuur teenwoordig nie; al wat hier is, is 'n ruimte wat gedeel word. Hier gaan dit oor jou en jou dansmaat. Julle kan vreemd vir mekaar wees en mekaar se bewegings nie so goed ken nie. Die uitdaging in die danssaal is dat al is die dans-vanvrede nie so vloeiend nie, albei dansers die proses sal respekteer. Dit kan tyd neem om mekaar te leer ken in die proses. Tyd om te verstaan, tyd om gewoond te raak. Die volgende kan as algemene kenmerke van so ' $n$ danssaal beskou word:

- 'n Teologie van affirmasie.

- In die saal is daar'n geur wat gekenmerk word deur interpatie - ons luister graag na jou, ons wil weet en stel belang, maar meer nog, jou siening en perspektief is vir ons belangrik.

- In die danssaal maak ons nie net oogkontak nie, maar komplementeer ons bewegings mekaar - dit wat tussen ons gebeur, is skeppend en uniek, dit skep 'n verdere ruimte.

- Die altyd bewegende, nooit gearriveerde, etos van die Nederduits Hervormde Kerk van Afrika (NHKA) kan in die dans waargeneem word in die mens as ' $n$ mens deur ander mense, binne' $n$ bepaalde nis.

- In hierdie verhouding wat dansmaats met mekaar het, gebeur daar iets generatief vir die hele gemeenskap. Die dans word nou 'n ruimte vir nuwe en transformerende oomblikke van oorvertel, van konstruering van nuwe verhale.

- In die danssaal, wanneer ons besig is met die dans-vanvrede, is ons nie alleen nie. Ons staan daar voor die res van die gemeenskap wat saam met ons die dans geniet.

\section{Ons dans op die ritme van die evangelie in die dans- van-vrede}

Vanuit die hervertelde noodverhale van die medenavorsers op ons reis, was dit duidelik dat 'n verbeelde toekomsverhaal wel moontlik is in die konteks van genoegsame ruimte binne die NHKA in terme van die verhouding tussen predikant en lidmaat in die Kerk. Ons kan sê dat dit geskied op grond van die musiek wat in die danssaal gehoor word. Dit kan ook gesien word as die taal wat hulle gebruik om die Meesternarratief van God voor te stel. $\mathrm{Al}$ die gespreksgenote beleef ' $\mathrm{n}$ roepingsbewustheid. Hulle beskryf dit eerder as ' $n$ verantwoordelikheid teenoor 
God en nie teenoor 'n kerkraad of gemeentegroep nie. Die beste manier om dit te beskryf, is in terme van 'n Coram Deo. Hulle beleef ' $n$ lewe voor God. Dit maak hulle deeglik bewus van die musiek in die danssaal. Dit beskou hulle as die evangelie van Christus. Die musiek word deur almal in die danssaal gehoor, die verskil is egter die manier waarop ons reageer wanneer ons die musiek hoor. Ons koppel ons eie unieke ritme aan die wysie van die musiek. Dit skep ruimte vir diversiteit in die danssaal. Geen twee mense se dans sal op dieselfde manier gekonstrueer word nie. Dit verskil van dansmaats tot dansmaats, alhoewel ons dieselfde musiek hoor. Skrifbeskouings wissel, want dit word gevoed vanuit verskillende wêreldbeskouings en perspektiewe. Daarom, al is die teks dieselfde, toon die res van die hermeneutiese proses verskillende reaksies en optredes. Ons het dus in die danssaal te doen met verskillende danse op grond van die musiek wat gespeel word. Elkeen toon fragmente van dit wat hulle hoor. Elkeen toon fragmente van 'n ware, nie absolute nie, belewing of ervaring van die musiek wat deur die Musiekmaker gespeel word.

Ons beskou 'waarheid' in die dansaal dus nie as 'iets' nie dit kan nie gesien word as die dak van die saal nie - want dit het perke; as ons vaskyk teen die dak word ons nie beweeg na randvorme van taal nie, maar bly ons vasgevang in die 'amptelike' raamwerk of struktuur van die danssaal. Nee, die dak stel eerder' $n$ ' universum van simbole' saam wat, afhangende van waar jy op die dansvloer is, kan verskil van mededansers in die danssaal. Die 'waarheid' vir ons in die danssaal kan eerder gesien word as die musiek (openbaring) wat ons hoor en die sekerheid dat daar lemand is wat die musiek maak, of gemaak het in die danssaal. Waarheid in die 'nuwe' gemeenskap van die danssaal is die Iemand wat met elke danser in gesprek is.

\section{'n Liminale hangbrug van genade}

Op ons navorsingsreis het ons nou 'n plek bereik waar oorbeweeg kan word van een wêreld na 'n ander wêreld. Die medenavorsers sien die huidige wêreld as een wat bedreig word deur ' $n$ aantal faktore binne die NHKA en ontwikkelinge wat parallel loop met die verhaal van die Kerk. Hierdie verhale en kontraverhale in die noodverhale van die medenavorsers het veroorsaak dat hulle op hul eie reis in die Kerk hulself in 'n vasgeloopte verhaal bevind. Die voorstel van die metafoor van die liminale hangbrug van genade dui op 'n alternatiewe verhaal in die reismetafoor van die navorsing.

Met ander woorde, nou kan ons sien dat ons op hierdie reis gearriveer het by 'n plek waar daar 'n groot kloof is, 'n opening, 'n bepaalde skeur wat ons reis versper. Die enigste manier om verder te reis oor hierdie abyss, hierdie bodemlose put, is om gebruik te maak van die stukkende hangbrug wat geen struktuur toon nie. Dit kan beskou word as die liminale ruimte.

\section{Die brug sonder struktuur vra oomblikke van kreatiwiteit}

'n Liminale fase van 'oorgang' toon in die praktyk anti-struktuur as kenmerk. Dit is presies waar ons nou staan op hierdie navorsingsreis. Die vraag is: Indien daar geen struktuur gesien kan word nie, op watter wyse kan ons die pad van oorgang in hierdie reis beskryf? Wanneer die struktuur ontbreek, kan ons die klem plaas op die verskynsel van communitas. Dit is in die verhouding van mense tot mekaar dat die hangbrug waargeneem kan word. Ons het mekaar nodig om hierdie brug vas te hou. Dit impliseer vertroue in mekaar. As dit nie vir die ander is nie, kan ek nie van hierdie wêreld (wat gekenmerk word deur gevare en bedreiging) na 'n ander kant of wêreld beweeg nie. Wanneer ons een-een oor hierdie brug beweeg, het ons mekaar dus in gedagte. Sonder die een, kan die ander nie meer bestaan nie.

Die proses van 'oorgang' oor die bodemlose put vra verder dat ons binne onsself oomblikke van andersheid sal beleef. Dit vra dat daar by ons nie net een perspektief is nie, maar twee, dat daar nie net een interpretasie teenwoordig sal wees nie, maar ook die interpretasie van die ander. Ons is net wie ons is vanuit die andersheid van die ander wat die hangbrug vir ons vashou. Verder is dit duidelik dat ons eie verhale gesien kan word as deel van die prefigurasie (mimesis 1), en dat die onsekere hangbrug gesien kan word as die oorgang (mimesis 2 of konfigurasie) wat ons uiteindelik bring by die voltooide hermeneutiese proses van refigurasie (of mimesis 3 ).

In hierdie oomblikke van kreatiwiteit of die vorming van denkbeelde word oor die brug wegbeweeg van die 'tegniese manier van denke' na oomblikke van 'om nie te weet nie', waar nie een van ons in die reis ' $n$ antwoord het op al die vrae wat ons vra nie. Dit kan eerder beskou word as onseker en botsend met die manier waarop ons in die verlede na die instituut van die Kerk gekyk het. Ek stem hier saam met Müller (Poetical pastoral counselling) dat die waarheid in die proses tot ' $\mathrm{n}$ groot mate gereduseer word. Met so 'n manier van dink (tegniese manier van dink), kan die evangelie gesien word as 'n ou gewoonte op die reis in die Kerk. Verder kan tegniese denke die misterieuse as 'n probleem beskryf, dit kan kwaliteit na kwantiteit verander, dit kan selfs Bybelse geloof verander in bestuurbare vorme. In die oomblikke van kreatiwiteit en verbeelding word ons in die reis beweeg: weg van die probleem na die misterieuse; weg van sekerheid na versekering; weg van kwantiteit na kwaliteit.

Volgens Gerkin (1986:60) kan praktiese teologie gesien word as interdissiplinêr met verskeie tale in sy aksie. Praktiese teologie is gebore uit die Christelike praxis van die mens. So kan praktiese teologie gesien word as nooit afgehandel nie, dit bly altyd in proses. Gerkin (1986) beskryf praktiese teologie vanuit 'n narratiewe hermeneutiese benadering soos volg:

Practical theology, seen from a narrative hermeneutical perspective, involves a process of the interpretive fusion of horizons of meaning embodied in the Christian narrative with other horizons that inform and shape perceptions in the various arenas of activity in which Christians participate.

(Gerkin 1986:61)

Wanneer een paradigma oorbeweeg na 'n volgende, gebeur dit dat konvensionele denkpatrone uitgedaag word en selfs disintegreer. Die leser/hoorder word ingetrek in 'n narratief, en die verhaal het die krag om hulle te verander. Dit kan gesien word in terme van Ricoeur se werking van mimesis. Volgens Dreyer (2003:326) het mimesis te doen met die tekstuur van die narratief. Die eerste mimesis (of prefigurasie) kan gesien word as die aktiwiteit van die outeur of verteller wat 'n teks skep. Die betrokkenheid van die leser/hoorder kan gesien word as die tweede mimesis (konfigurasie). Die leser/hoorder se voortgaande lewe as ' $n$ transformatiewe lewe kan verstaan word as die derde mimesis (of refigurasie). Daar word ook na die proses verwys as die sogenaamde 'hermeneutiese boog' van Ricoeur. Wat belangrik is, is om in te sien dat die leser/hoorder die een is wat met die daad van lees/luister die handeling uitvoer wat 'n eenheid skep van die eerste mimesis na die derde mimesis deur middel van die tweede mimesis.

In die narratief volg ' $n$ aantal strategieë in die hermeneutiese proses. Dreyer (2003:327) sien die motiewe, redes waarom iemand iets gedoen het, as die beginpunt. Wat die karakters motiveer, hou direk verband met wat gebeur het of nie. Karakters kan beskryf word as agente wat funksies soos protagonis, antagonis of helper vervul. Agente soos deur die verteller bepaal, is verantwoordelik vir die gevolge van hul optrede. Die vraag na die motiewe kan gesien word as die 'waarom'vraag. Die antwoord op die 'wie'-vraag is meer beperk as dié van die 'waarom'-vraag, maar tog kan die twee nie van mekaar losgemaak word nie. Die antwoorde op die vrae 'wat', 'waarom', 'wie', 'hoe', 'met wie' of 'teen wie' van 'n handeling is verweef met mekaar en verwys oor en weer na mekaar. Die rekonstruksie van 'herinneringe' vra in die narratiewe hermeneutiek 'n ander logika as dié van die positivisme. 'n Abduktiewe epistemologie se uitgangspunt is dat kennis relatief is en dat alle tekens in taalhandelinge simbole is (Dreyer 2003:328). 
Op die brug hoor ons stemme uit ander wêrelde

In die oorgang van dié kant na die ander kant, word ons blootgestel aan sekere artefakte in die ritueel van oorbeweeg. Dit vra van ons, wanneer ons hierdie stemme hoor, dat ons vanuit ons eie verhaal die stemme sal artikuleer om sodoende die stemme te herinterpreteer en tot nuwe verstaan te kom, wanneer ons die ander kant van die hangbrug bereik het.

Die vraag is: Watter stemme hoor ons in hierdie 'oorgaan' op die hangbrug?

Müller (Poetical pastoral counselling) beskryf dit in terme van Brueggeman wat hierdie reis sien as 'n roete na die rand van alternatiewe. In so 'n beweging ontmoet stemme mekaar. Hier kan die volgende gesien word: Die tekste waarvolgens mense lewe, die waarhede en wysheid, word gevorm na ideologiese diskoerse; die gespreksgenote; die oomblik van gesprek; die verbeelde toekoms ontmoet mekaar op hierdie brug van transformasie. So 'n ontmoeting en vertelling daarvan nooi ons uit om die wêreld op 'n ander manier te sien. Wanneer so iets gebeur, beleef ons volgens Müller 'n katarsis - iets wat beskou kan word as 'n kenmerk van die liminale brug van genade. Dit is duidelik dat 'n kortsluiting gesien kan word as kenmerkend van die liminale ruimte. Vir praktiese teologie is die vraag: Hoe kan hierdie kortsluiting aanleiding gee tot transformasie?

\section{'n Brug wat dui op transformering}

Die oomblik toe ons op ons navorsingsreis gekonfronteer is met hierdie liminale hangbrug van genade, het daar reeds iets met ons verstaan van ons eie verhale en dié van ander gebeur. Die gevare en die kloof het vir ons aangedui dat ons op hierdie reis 'n plan sal moet maak om in beter omstandighede verder te kan reis. Hier het dus 'n beweging plaasgevind waar ons deur middel van reframing weer terug kon kyk op die reis en kon besluit hoe ons die reis vorentoe kan aanpak.

Ons besef ook dat ons nie oor die bodemlose 'put' kan kom sonder om 'n sekere vertroue in mekaar te stel nie. Hierdie communitas en kameraadskap wat tussen ons ontstaan op die reis, juis as gevolg van die hangbrug, beweeg ons van sekerheid na versekering in die opsig dat al weet ons nie wat alles op die reis voorlê nie, ons nou aan 'n gemeenskap van reisigers behoort wat ons in die proses nie sal los nie, maar die klowe van die lewe saam met ons sal aanpak. Die tekste van die lewe wat ons vertel, ons eie ideologieë (wat gevoed word deur verskillende wêreldbeelde), het op hierdie hangbrug ook verander in gereduseerde waarhede. Dit het veroorsaak dat ons ruimte kon vind vir mekaar op hierdie navorsingsreis.

Dit is duidelik dat wanneer ons saam oor hierdie brug is, dinge anders gaan wees. Ons kan sê dat ons lewensverhale wat partykeer as vasgeloopte verhale beskou is, getransformeer is tot 'n ruimte van wees saam met ander. 'n Ruimte in die Kerk (NHKA) waar ons vir die aanslae of krisisse wat ons in verhoudings beleef, veral in die verhouding tussen predikant en lidmaat, heling kan vind in terme van 'n onsekere, ongestruktureerde hangbrug waar al die partye mekaar nodig het om te kan oorleef - om 'n nuut gekonstrueerde, alternatiewe verhaal te vertel.

\section{'n Brug van genade}

Die navorsers op die navorsingsreis het gekies om hierdie onsekere brug te beskryf as 'n weg van genade. Dit beskryf iets van die Groter Meesternarratief van God. Deur na te dink oor hul eie reis in die NHKA, sien hulle die liminale ruimte as ' $n$ ruimte wat beskryf kan word in terme van Godstaal.

Dié taal klink anders as die taal wat gebruik is aan die begin van die reis. In terme van vaste reëls en ordinansies van die instituut waar waarheidsuitsprake en beelde van God gesien kan word as absoluut en vas, word in die metafoor, wat ook aan die huidige stand van sake gekoppel word - met ander woorde wat ook nie as vas en seker beskou kan word nie - nou beweeg na 'n taal waar moontlikhede in inkongruensie tussen predikant en lidmaat beskou kan word as genade of geleende tyd, waar God vir ons 'n geleentheid skep om na mekaar te luister binne die ruimte van die NHKA en meer spesifiek in die gemeente.

Ons kan dus sê dat 'n brug van genade ons ook anders laat dink oor God en die openbaring van God en die manier waarop dit horisontaal vir ons reisigers tot gestalte kom. In hierdie manier om oor God te praat, sien die medenavorsers God as gewer van die brug wat gebou word binne die sosiale konteks van die lidmate in die gemeente. Anders gestel, kan ons sê dat God ons gebruik om hierdie hangbrug te bou om van een plek na 'n ander te kan beweeg. Dit veronderstel 'n imperatief binne die praxis in 'n praktiese hermeneuties-teologiese model wat die konteks in ag neem. In so 'n model vir praktiese teologie verteenwoordig die indikatiewe die getuienis van die Woord van God wat gesentreer is in die openbaring van Christus. Die imperatief kan gesien word as gevorm deur die effek van die menslike situasie deur die indikatief. So 'n model gaan uit van die voorverstaan dat 'n vernuwende praxis altyd in konteks geskied.

Die term van genade binne die beskrywing van die liminale brug kan dus verstaan word in terme van die helende werking van Christus in menslike verhoudings.

In die teologie beskou teoloë soos Cilliërs die liminale ruimte as 'n 'oopbreek' ruimte - 'n ruimte waar die gelowige ontsnap van die struktuur rondom hom of haar en waar hulle opnuut weer soek na identiteit sowel as struktuur.

Kenmerkend van hierdie ruimte is dat dit altyd gesien kan word as bloot tydelik en dat in so ' $n$ ruimte meer as een perspektief gelyktydig waar kan wees oor die gemeenskap en die groep.

\section{DIT VRA VERTROUE}

Dit wil voorkom asof die vraagstukke wat tans op die tafel van die NHKA is ' $n$ verhaal vertel. ' $n$ Verhaal van meer as een perspektief, 'n verhaal van mense wat ruimtes en veilige tuistes probeer beskerm. Dit kan baie vinnig ontaard in ' $n$ situasie waar een gelowige ' $n$ bedreiging vir ' $n$ ander word. Die vraag is: In watter mate kan die Kerk oor hierdie hangbrug van gevaar beweeg? Hoe kan ons van een punt van die reis na die volgende gaan? Hierdie hangbrug vra oomblikke van kreatiwiteit, waar ons oor die abyss van verskille en perspektiewe kan beweeg na 'n ruimte waar ons mekaar in besonder kan vertrou. Die oor die grens beweeg vra van die Kerk 'n wegbeweeg van die 'tegniese manier van dink' na 'n 'nie-wetende' ontdekkingstog. Ons word wegbeweeg van die probleem na die misterieuse, weg van sekerheid na versekering, weg van kwantiteit na kwaliteit. Ons besef dat ons nie oor die bodemlose put kan kom sonder om die brug vir mekaar vas te hou nie. Dit vra vertroue in die persoon wat die brug vir jou vashou. Hierdie communitas word sigbaar wanneer ons terugkyk op die hangbrug, maar al wat ons nou kan sien, is die katarsis van die hangbrug wat voor ons lê. Dit is duidelik dat wanneer ons saam oor hierdie hangbrug is, dinge anders gaan wees.

Dit kan die praktiese teologie na 'n meer uitgebreide ruimte bring, waar ander gesprekke gevoer kan word met ander ruimtes binne ander dissiplines in die NHKA. Met die voorstel van ' $n$ dans-van-vrede en die liminale brug van genade as metafore in die bedieningsverhouding tussen predikant en lidmaat met die perspektief om diversiteit in die verhouding konstruktief aan te wend, kan dan weer gevra word om bedieningspraktyke binne gemeentes in die NHKA te herinterpreteer ten opsigte van 'n ruimte waar opnuut gefokus kan word op sosiale interaksie as 'n imperatief in die bedieningspraxis.

Die ervaring van communitas dui op 'n unieke perspektief in 'n liminale fase waarbinne die NHKA 'n verbeelde toekomsverhaal kan vertel. In die afkeur of afwesigheid van struktuur, of die opstand teen institusie, kan dit 'n moontlike ruimte daarstel 
waarbinne die Kerk weer 'n postliminale ruimte kan bereik - 'n oomblik van harmonisering.

Dit is duidelik dat daar in die hervertelde verhale van die medenavorsers oomblikke van lig deurskemer. Op 'n denkbeeldige weg van dans of oorgang oor 'n brug, kan die reis van hierdie navorsing gesien word as 'n verhaal van hoop. Hoop ondanks die verhale wat daarvan getuig dat hulle bedreig word in die wêreld. Ons sien lig aan die einde van die tonnel, alhoewel hierdie hoop gepaardgaan met ernstige selfondersoek en introspeksie wanneer dit kom by ons eie verhale te midde van die magdom verhale wat daarbuite vertel word.

Die navorsing het ons na 'n plek geneem waar ons sal moet besluit: Gaan ek die uitnodiging aanvaar om deel te neem aan die dans-van-vrede? Sien ek kans om my medereisgenoot in die Kerk (NHKA) genoeg te vertrou dat hy of sy my sal vashou wanneer ek oor hierdie liminale hangbrug van genade loop?

Indien jy besluit dat jy wel kans sien, wag daar vir ons op die reis vorentoe ongekende oomblikke in die Kerk. Oomblikke waar ons so 'n sterk band met ons broer en suster in geloof het, dat ons hulle werklik sal kan vertrou met ons lewe.

\section{LITERATUURVERWYSINGS}

Bons-Storm, R., 2008, 'A place to share: Some thoughts about the meaning of territory and boundaries in our thinking about God and humanity ['n Plek om te deel: Enkele gedagtes oor die betekenis van grondgebied en grense in ons denke oor God en die mensdom]', HTS Teologiese Studies/Theological Studies 64(1), 141-153.

Buitendag, J., 2002, 'Karl Heim se verstaan van ruimte in die debat tussen die teologie en natuurwetenskap', Verbum et Ecclesia 23(2), 291-304.

Cilliërs, J.H., 2007, 'Religious and cultural transformations and the challenges for the churches: A South African perspective [Godsdienstige en kulturele transformasie en die uitdagings vir die kerke: 'n Suid-Afrikaanse perspektief]', Praktiese Teologie in Suid-Afrika 22(2), 1-19.

Dreyer, Y., 2002, 'Part II. Leadership in the world of the Bible: (De) institutionalisation as an ongoing process [Deel II. Leierskap in die wêreld van die Bybel: (De) institusionalisering as ' $\mathrm{n}$ voortdurende proses]', Verbum et Ecclesia 23(3), 625-641.

Dreyer, Y., 2003, "n Teoretiese inleiding tot narratiewe hermeneutiek in die teologie', Hervormde Teologiese Studies' 59(2), 313-332.

Dreyer, T.F.J., 2006, 'Die akkommodering en bestuur van diversiteit in gemeenteverband' Hervormde Teologiese Studies 62(4), 1291-1309.

Ericson, M., 2006, 'Making and sharing the space: Initiatives for story-telling and reconciliation among woman and men in South Africa and Northern Ireland [Die skep en deel van die spasie: Die aanvang van storie vertelling en versoening onder vroue en mans in Suid-Afrika en Noord-Ierland]', Nederduitse Gereformeerde Teologiese Tydskrif 47(3\&4), 455475.

Gergen, K.J., 2002, Reflecting on/with my companions [Besin oor/met my metgeselle], draft for the last chapter in Social constructionism and theology, ed. C. Hermans, G. Immink, A. de Jong \& J. van der Lans, Brill, Boston.
Gergen, K.J., n.d., Dialogue: Life and death of the organization [Dialoog: Lewe en dood van die organisasie], draft copy for the Handbook of Organizational Discourse, ed. D. Grant, C. Hardy, C. Oswick, N. Phillips and L. Putnam, Sage, Thousands Oaks, CA.

Gerkin, C.V., 1986, Widening the horizons. Pastoral responses to a fragmented society $[\mathrm{Om}$ die horisonne te verbreed. Pastorale reaksies teenoor 'n gefragmenteerde gemeenskap], The Westminster Press, Philadelphia.

Jonker, W.J., 2007, 'Geloofsverskille: Waar kom hulle vandaan en wat maak ons met hulle?', Verbum et Ecclesia 28(2), 442467.

Shults, LeRon F., 2006, The evolution of rationality. Interdisciplinary essays in honour of J. Wentzel van Huyssteen [Die evolusie van rasionaliteit. Interdisiplinêre verhandelinge in eer van J. Wentzel van Huyssteen], W.m.B. Eerdmans Publishing Co., Grand Rapids.

Müller, J.C., 2008, 'Postfoundationalism as a practical way of interdisciplinary work: Narrative research on HIV and Aids [Postfundamentalisme as 'n praktiese manier van interdisiplinêre werk: Narratiewe navorsing oor MIV en VIGS]', paper delivered at the Third International conference on Interdisciplinary Social Sciences, Prato, Italy, 22-25 July.

Müller, J.C., 2000, Reis-geselskap, Lux Verbi. BM, Kaapstad.

Müller, J.C., 2004, 'Imaginative pastoral counselling [Verbeeldingryke pastoral berading]', presented by J. Müller \& L. Human, Continuing Education, University of Pretoria, Pretoria, 21-22 April.

Meylahn, J.A., 2006, 'Postfoundationalism, deconstruction and the hope that motivates research in practical theology [Postfundamentalisme, dekonstruksie en die hoop wat navorsing motiveer in praktiese teologie]', HTS Teologiese Studies/Theological Studies 63(2), 983.

Oliver, E., 2006, 'Afrikaner spirituality: A complex mixture [Afrikaanse spiritualiteit: 'n Komplekse mengsel]', HTS Teologiese Studies/Theological Studies 62(4), 1469-1487.

Pieterse, H.J.C., 2005, 'Hoe kom God aan die woord in die prediking? Die werklikheid en taal waarin ons oor God praat', Praktiese Teologie in Suid-Afrika 22(1), 118-134.

Schutte, C.H. \& Dreyer, Y., 2006, 'An epistomological reflection on the relevance of monastic traditions for retreat in the Dutch Reformed tradition ['n Epistomologiese refleksie in terme van die relevansie van kloosterlike tradisies vir terugtog in die Nederduits Gereformeerde tradisie]', HTS Teologiese Studies/Theological Studies 62(3), 965-982.

Van Gennep, A., 2004, The Rites of passage [Die reg van toegang], Routledge, London.

Van Huyssteen, W., 1997, 'Should we be trying so hard to be postmodern? A Response to Drees Haught and Yeager [Moet ons so hard probeer om postmodern te wees? 'n Reaksie op Drees Haught en Yeager]', Zygon 32(4), 567-584.

Van Huyssteen, W., 2000, 'Postfoundationalism and interdisciplinarity: A response to Jerome Stone [Postfundamentalisme en interdissiplinariteit: 'n Reaksie op Jerome Stone]', Zygon 35(2), 427-439. 